\title{
Implementasi Sistem Pengendalian Intern Pemerintah (SPIP) Dalam Perspektif Islam
}

\author{
Arisman, Aries Putriyani, Ahmad Afandi \\ UIN Syarif Hidayatullah Jakarta \\ arisuin@gmail.com; ariesputriyani@uinjkt.ac.id; ahmad.afandi@uinjkt.ac.id
}

\begin{abstract}
The purpose of this study is to explore the implementation of Government's Internal Control System in Islamic perspective. This research used descriptive method with AlQur'an, Hadith, regulations, books and articles as the sources of this research. Although Internal Control's Comprehensive Framework and Guidance developed by COSO in 1992, but it had implemented by muslim leader since Nabi Muhammad's era until Turki Utsmani Dynasty's era. Five components of Internal Control that formed by COSO and adopted by government in PP No.60 2008 are control environment, risk assessment, control activities, information and communication, and monitoring, each components have subcomponents; and for control environment we suggest to add with the spiritual, nature and style of leadership. The basic component of internal control is control environment, because it has a role as a protector for other components. If control environment has worked properly, then it will minimize a risk, control activities would be implemented simply, information and communication will run smoothly and internal control could be monitored periodically.
\end{abstract}

Keyword: internal control, monitoring activities, control activities

\begin{abstract}
Abstrak
Tujuan dari penelitian ini adalah untuk mengeksplorasi implementasi sistem pengendalian internal pemerintah dalam perspektif Islam. Penelitian ini menggunakan metode deskriptif dengan Al-Qur'an, Hadis, peraturan, buku dan artikel sebagai sumber penelitian ini. Meskipun Kerangka Komprehensif dan Panduan Kontrol Internal dikembangkan oleh COSO pada tahun 1992, tetapi telah dilaksanakan oleh pemimpin muslim sejak era Nabi Muhammad sampai era Dinasti Turki Utsmani. Lima komponen Pengendalian Internal yang dibentuk oleh COSO dan diadopsi oleh pemerintah dalam PP No.60 Tahun 2008 adalah lingkungan pengendalian, penilaian risiko, aktivitas pengendalian, informasi dan komunikasi, dan pemantauan, setiap komponen memiliki subkomponen; dan untuk lingkungan pengendalian kami sarankan untuk menambahkan dengan spiritual, sifat dan gaya kepemimpinan. Komponen dasar pengendalian internal adalah lingkungan pengendalian, karena memiliki peran sebagai pelindung untuk komponen lain. Jika lingkungan pengendalian telah berfungsi dengan baik, maka akan meminimalkan risiko, kegiatan pengendalian akan dilaksanakan secara sederhana, informasi dan komunikasi akan berjalan dengan lancar dan pengendalian internal dapat dipantau secara berkala.
\end{abstract}

Kata Kunci: pengendalian internal, aktivitas pengawasan, kegiatan pengendalian

Diterima: 13 Agustus 2018 2108; Revisi: 2018; Disetujui: 2018 


\section{PENDAHULUAN}

Kata Pengendalian berasal dari bahasa Perancis "Contre" yang artinya melawan. Koontz dan Donnell mendefinisikan Pengendalian sebagai suatu tindakan yang dilakukan dengan mengukur dan menghubungkan kegiatankegiatan untuk memastikan bahwa peristiwa yang terjadi sesuai dengan rencana. Suatu tindakan pengendalian dapat mengungkapkan adanya suatu penyimpangan dan dapat membantu manajemen dalam menjamin terciptanya pemenuhan rencana yang ditetapkan. Sistem pengendalian internal menekankan pada kemampuan suatu institusi dalam mengelola organisasinya (Darmawan dkk, 2015).

Secara etimologis controlling lazimnya diterjemahkan dengan pengendalian atau pengawasan. Tery (1962) mengartikan pengendalian sebagai suatu usaha untuk meneliti kegiatan-kegiatan yang telah dilaksanakan. Pengendalian berorientasi pada objek yang dituju dan merupakan alat untuk memerintah orangorang dalam bekerja menuju sasaran yang ingin dicapai. Sulhan mendefinisikan pengendalian atau pengawasan adalah kegiatan mengukur efektifitas kerja personel dan tingkat efisiensi penggunaan metode dan alat tertentu dalam usaha mencapai tujuan. Menurut Siagian, sebagaimana yang dikutip Sulistiyorini, fungsi pengawasan yaitu upaya penyesuaian antara rencana yang telah disusun dengan pelaksanaan atau hasil yang benar-benar dicapai. Jadi yang dinamakan pengendalian atau pengawasan adalah suatu kegiatan untuk mengukur, menganilisis, menggambarkan serta mengoreksi pelaksanaan suatu rencana yang telah disusun agar berjalan dengan efektif.

Dalam perkembangan dunia bisnis saat ini, tindakan pengendalian yang dinilai cukup efektif adalah dengan menempatkan sistem pengendalian ke dalam tindakan preventive objective, dimana penyimpangan atau kekurangan dapat dicegah sedini mungkin. Tindakan ini sangat bergantung pada komitmen manajemen dalam melakukan pengelolaan dengan prinsip prudent, karena hal ini mungkin saja dapat berdampak pada ketidakefektifan manajemen. Oleh karena itu, perlu adanya pengembangan strategi bagi manajemen organisasi untuk 
menerapkan fungsi pengendalian namun tetap menjaga dinamika besar pada seluruh fungsi organisasi secara keseluruhan.

Dalam perspektif Islam, mungkin saja prinsip-prinsip pengendalian tidak sama dengan pendekatan konvensional. Dimana pada prinsipnya Islam mengacu pada pola syariah dalam setiap kegiatan muamalah, termasuk penerapan sistem pengendalian internal dalam organisasi. Proses bisnis, mekanisme Pengendalian internal atau eksternal, Pengendalian pribadi dan sosial atau legalitas hukum tidak boleh melanggar prinsip-prinsip dasar syariah.

Konsep penerapan pengendalian pada perusahaan dapat diaplikasikan menggunakan tiga komponen utama) yakni sebagai berikut: pertama, Menetapkan standar kinerja (Standard operating procedures); Kedua, internalisasi, sosialisasi, dan uji coba SOP pada seluruh user sebelum diimplementasikan; Ketiga, menetapkan tindakan monitoring dan langkah-langkah perbaikan.

Proses pengendalian dalam Islam dapat dijelaskan dengan menganalogikan proses pengendalian pada manajemen diatas dengan filosofi ajaran Islam. Berdasarkan histori dan filosofi ajaran Islam dari berbagai sumber ilmu pengetahuan, gambaran umumnya adalah sebagai berikut: Pertama, sebuah pesan dalam hal ini peraturan, ketentuan, ketetapan baik berupa perintah maupun larangan, janji serta hukuman dibuat dan ditetapkan oleh Allah SWT yang ditujukan untuk seluruh manusia. Hal ini menjadi standar utama yang harus dipatuhi oleh seluruh umat manusia. Kedua, Rasul mengkomunikasikan pesan tersebut kepada manusia dengan menuangkannya ke dalam Al-Qur'an kemudian disyiarkan melalui dakwah dengan berbagai macam metodologi. Ini merupakan proses internalisasi kepada semua manusia dalam menjalankan kehidupan. Ketiga, banyak orang yang menerima, memahami dan mengimplementasikan semua standar yang ditetapkan oleh Allah SWT melalui Rasullullah. Keempat, banyak pula dari mereka yang mengabaikan (melakukan penolakan) dan tetap menjalankan praktek lama mereka (mempersekutukan Allah), untuk kemudian melawan standar yang telah ditetapkan. Kelima, sebagai tindakan perbaikan, Allah SWT 
memberikan kesempatan kepada manusia yang telah menyimpang dari aturan/standar yang ditetapkan untuk bertaubat (permintaan maaf).

Dalam upaya memperluas cakupan informasi, selanjutnya proses analogi sistem pengendalian internal basis konvensional dengan basis syariat Islam, maka perlu mengambil contoh pola pengendalian pemerintah pada zaman kekhalifahan. Sebagai contoh sistem pengendalian dalam Islam, yakni pada zaman kekhalifahan Umar bin Khattab (Ra) yakni Khalifah kedua umat Islam.

Dalam menjalankan pemerintahannya, Umar mengatur dan menentukan luas/ruang lingkup tugas komandan dan para gubernur. Dia juga memberikan arahan kepada setiap aparat pemerintah bahwa harus mengikuti arah umum kebijakan, dan menempatkannya diatas kepentingan pribadi, walaupun mereka juga memiliki hak kebebasan individu. 'Umar juga mengevaluasi dan menentukan bagian tugas mana yang sulit, untuk kemudian menambah sumber daya agar tujuan yang ingin dicapai dapat terwujud.

Dari hasil analogi dan riwayat para pemerintahan sahabat Nabi diatas dapat diambil kesimpulan sederhana bahwa pengendalian manajemen memiliki proses yang sama diantara dua pendekatan, yakni pendekatan pengendalian konvensional dan pengendalian dalam Islam. Sistem pengendalian konvensional yang saat ini banyak dikenal dengan istilah COSO yang dikeluarkan oleh suatu lembaga yakni Committee of Sponsoring Organization of The Treadway Commision yang memperkenalkan 5 komponen dalam pengendalian internal yaitu lingkungan pengendalian, penilaian risiko, aktivitas pengendalian, informasi dan komunikasi serta pemantauan, sedangkan CoCo dikeluarkan oleh suatu lembaga The Canadian Institute of Chartered Accountants Criteria of Control Committee, mereka menyusun model pengendalian yang teridiri dari 4 (empat) komponen yaitu purpose, commitment, capability, monitoring dan learning. COSO dan CoCo merupakan produk yang baru ditemukan, dikembangkan dan diterapkan di zaman modern ini, sementara pemerintahan Umar bin Khattab (Ra) sudah mengimplementasikan jauh sebelum berkembangnya ilmu pengetahuan. Umar selalu mengaplikasikan Syariat Islam yang diajarkan, dicontohkan dan diperlihatkan oleh Nabi Muhammad SAW pada aktivitas pengendalian pada pemerintahanya. 
Peneliti berpandangan, bahwa dalam ajaran Islam yang tertuang dalam $\mathrm{Al}$ Quran dan Hadist mengajarkan ilmu tentang pengendalian. Dimana konsep sistem pengendalian yang sudah diterapkan sejak jaman kekhalifahan dengan basis syariat Islam, namun hanya saja sistem tersebut secara implisit dilakukan dan tidak dibukukan.

Penelitian ini bertujuan untuk: Pertama, untuk mengetahui bagaimana implementasi Pengendalian Internal pada Pemerintahan dalam Islam. Kedua, untuk melihat komponen apa yang paling mendasar dalam pengendalian internal pada pemerintah dengan basis syari'at Islam.

Penelitian ini diharapkan dapat memberikan manfaat, yaitu: pertama, dapat memberikan pengetahuan dan informasi baru tentang konsep pengendalian internal Pemerintah dengan basis syariah. Kedua, dapat memberikan referensi tambahan dalam merancang sistem pengendalian internal Pemerintah yang menitikberatkan pada nilai-nilai dan prinsip Islam. Ketiga, dapat memberikan ruang baru dalam kajian ilmu ekonomi manajemen untuk pengembangan cabang ilmu lainnya yang berbasis syariat Islam. Keempat, dapat menambah pengetahuan dalam mengembangkan dan mengelola sistem manajemen pemerintahan.

\section{METODE}

Penelitian ini bersifat kualitatif, riset kualitatif merupakan suatu penelitian yang mendalam (in-depth) berorientasi pada kasus dari sejumlah kecil kasus, termasuk satu studi kasus. Tujuan utama riset kualitatif adlah untuk membuat suatu fakta dapat dipahami, dan sering kali tidak terlalu menekankan pada penarikan kesimpulan, atau tidak menekankan pada perkiraan (prediksi) dari berbagai pola (yang ditemukan) (Morissan, 2015).

Prosedur pengolahan data yang dilakukan adalah sebagai berikut: Pertama, Proses pembahasan masing-masing konsep pengendalian di masa kepemimpinan Islam seperti pada masa Rasulullah SAW, pada masa Khulafa al Rasyidun (Abu Bakar, Umar Ibn Khattab, Usman Ibn Affan, Ali Bin Abi Thalib, Daulah Muawiyah, Daulah Abbasiyah, Daulah Turki Usmani), konsep pengendalian dalam Peraturan 
Pemerintah Nomor 60 Tahun 2008 serta konsep pengendalian Commite of Sponsoring Organization of the Treadway Commission (COSO). Kedua, Proses analisa komparasi untuk melihat implementasi antara konsep yang dilakukan pada masa kepemimpinan Islam dengan konsep yang telah dibangun oleh COSO.

Penelitian ini menggunakan pemeriksaan keabsahan data dengan pengujian credibility yaitu triangulasi. Triangulasi di artikan sebagai pengecekan data dari berbagai sumber dengan berbagai cara dan berbagai waktu. Triangulasi yang digunakan adalah triangulasi sumber dengan melakukan kroscek atas datadata yang diperoleh peneliti dari berbagai sumber literatur reviu.

Dalam melakukan analisa data, terdapat 3 langkah yang harus dilakukan yakni (Sugiyono, 2013): Pertama, reduksi data, yakni merangkum, memilih hal-hal yang pokok, memfokuskan pada hal-hal yang penting dicari tema dan polanya. Sehingga memudahkan peneliti dalam melakukan pengumpulan data. Diawali dengan proses pembahasan masing-masing konsep pengendalian di masa kepemimpinan Islam seperti pada masa Rasulullah SAW, pada masa Khulafa al Rasyidun (Abu Bakar, Umar Ibn Khattab, Usman Ibn Affan, Ali Bin Abi Thalib, Daulah Muawiyah, Daulah Abbasiyah, Daulah Turki Usmani), konsep pengendalian dalam Peraturan Pemerintah Nomor 60 Tahun 2008 serta konsep pengendalian Commite of Sponsoring Organization of the Treadway Commission (COSO).

Kedua, display Data, penyajian data berupa teks bersifat naratif sehingga akan memudahkan peneliti dalam memahami apa yang terjadi dan merencanakan langkah selanjutnya yakni analisa komparasi untuk melihat implementasi antara konsep yang dilakukan pada masa kepemimpinan Islam dengan konsep yang telah dibangun oleh COSO. Ketiga, verifikasi data, berupa penarikan kesimpulan dan verifikasi.

\section{HASIL DAN PEMBAHASAN}

Hasil analisis atas pengujian hipotesis terkait bagaimana pola implementasi pengendalian internal pada pemerintahan dengan basis syariat Islam menunjukkan bahwa pada zaman pemerintahan Islam terdahulu, mereka menjalankan roda pemerintahan dengan berpedoman pada Al-Quran dan Hadits. 
Komponen pengendalian COSO belum dikenal pada saat itu sehingga mereka belum menggunakan komponen COSO dalam membentuk pengendalian, tetapi mereka menggunakan petunjuk yang tertuang dalam al-quran dan hadits dalam menjalankan sistem pengendalian pada tiap-tiap aktivitas pemerintahan. COSO merupakan sistem pengendalian yang ditetapkan akibat munculnya banyak kasus kecurangan yang terjadi di negara-negara, untuk meminimalisasi hal tersebut maka pemerintah membentuk komponen pengendalian yang diberlakukan untuk seluruh manajemen dalam menjalankan roda perekenomian.

Pemerintahan tidak terlepas dari unsur politik dan kekuasaan, kekuasaan menurut Ibnu Khaldun sebenarnya terbentuk melalui kemenangan suatu kelompok tertentu atas lainnya. Kekuasaan itu merupakan kedudukan menyenangkan, meliputi berbagai kesenangan materi maupun maknawi, material maupun spiritual, visible maupun invisible sehingga untuk mendapatkannya seringkali melalui kompetisi-kompetisi menggemparkan dan sedikit orang yang mau menyerahkannya.

Bentuk pengendalian internal pada pemerintahan dengan basis syariah dimulai dari lingkungan pengendalian. Lingkungan pengendalian merupakan inti dari komponen pengendalian lainnya, karena dalam lingkungan pengendalian karakter seseorang akan terbentuk oleh kondisi atau keadaan disekitarnya sehingga karakter tersebut dapat terbentuk sejak dini. Karakter Rasulullah misalnya dengan budi pekerti dan sifat-sifat yang dimiliki, pengetahuan dan wawasan yang luas dalam memberikan penjelasan dan menjawab pertanyaanpertanyaan dari berbagai pihak baik bersifat keagamaan maupun umum, hal ini menunjukkan karakternya telah terbentuk sehingga akan mampu dalam mengemban amanah yang telah diberikan.

Konsep lingkungan pengendalian COSO belum memasukkan sub komponen berupa spiritualitas, sifat dan gaya kepemimpinan yang dimiliki oleh Rasulullah pada masa itu diantara sifat dan gaya kepemimpinan beliau selama menjadi pemimpin negara adalah visioner, berkemampuan kuat, integritas, amanah, berani, pembelajaran antisipatoris, cerdas, berakhlak mulia dan memiliki kemampuan self 
leadership. Pada usia 12 tahun, Nabi ikut serta dalam perjalanan dagang ke Syria bersama pamannya, Abu Thalib. Setelah dewasa Beliau pun berinisiatif untuk berdagang. Dalam menjalankan usaha dagangannya, Muhammad SAW menggunakan modal orang lain yang berasal dari para janda kaya dan anak yatim yang tidak mampu menjalankan modalnya sendiri, dari menjalankan usahanya ia mendapat upah sebagai mitra. Semenjak itu beliaupun sering melakukan perjalanan keberbagai negeri seperti Syria, Yaman dan Bahrain untuk berdagang. Kepiawaiannya dalam berdagang yang disertai dengan reputasi dan integritas yang baik membuat Muhammad SAW dijuluki Al-Amin (terpercaya) dan AshShiddiq (jujur) oleh penduduk Mekkah (Amalia, 2005). Akhlak dan Kebiasaan Rasulullah SAW antara lain Kebersihan Lahiriah, Akal pemikiran dan kecerdasan, Kefasihan lisan dan keelokan ucapan, Kemurahan dan kedermawanan, Keberanian, Malu dan Menundukkan Pandangan, Baik pergaulan dan adabnya, Simpati dan Belas Kasih, Menepati janji dan menyambung silaturrahimi, Ketawadluan, Keadilan, dan amanah.

Dalam menjalankan roda pemerintahannya para pimpinan Islam banyak tindakan-tindakan yang merupakan langkah antisipatif dalam membentuk lingkungan pengendalian. Sifat-sifat yang dimiliki, pengetahuan agama yang baik, gaya kepemimpinannya serta penetapan kebijakan dan pengelolaan sumber daya manusia merupakan tehnik dalam membentuk lingkungan pengendalian yang baik. Bila semua hal-hal tersebut telah dimiliki maka mudah untuk membentuk lingkungan pengendalian yang sesuai dengan al-quran dan hadits karena para pemimpin Islam terdahulu selalu berpedoman kepada dua hal tersebut.

Pada masa sahabat Rasulullah, banyak kemajuan dan perkembangan yang terjadi mula dari ekspansi negara karena menang dalam peperangan, kemajuan teknologi dengan melakukan pencetakan mata uang negara, pembangunan tempat pendidikan, membentuk organisasi kepolisian guna menjaga sistem pertahanan dan keamanan, melarang pejabat menerima hadiah dan merangkap jabatan dalam beraktivitas. Hal tersebut merupakan bagian dari wara yang meminimalisasi kemudharatan-kemudharatan atas setiap aktivitas atau menilai risiko yang akan terjadi nantinya dan berdampak pada stabilitas negara. 
Setelah Nabi Muhammad SAW wafat, pemerintahan di gantikan oleh Abu Bakar, masa pemerintahannya hanya berlangsung dua tahun. Pada masa ini Abu Bakar banyak menghadapi persoalan dalam negeri yang berasal dari kelompok murtad, nabi palsu dan pembangkang zakat. Dalam usahanya meningkatkan kesejahteraan umat Islam, Abu Bakar ash-Shiddiq melaksanakan berbagai kebijakan ekonomi seperti yang telah dipraktekan Rasulullah SAW. Ia sangat memperhatikan keakuratan penghitungan zakat sehingga tidak terjadi kelebihan atau kekurangan pembayarannya. Hasil pengumpulan zakat tersebut dijadikan sebagai pendapatan negara dan disimpan dalam baitul mal untuk langsung didistribusikan seluruhnya kepada kaum muslimin hingga tidak ada tersisa.

Aktivitas pengendalian yang baik akan menghasilkan informasi yang akurat sehingga dapat mengkomunikasikan informasi tersebut kepada pihak-pihak tertentu untuk dapat mengambil keputusan yang tepat. Keputusan yang tepat dapat dituangkan melalui kebijakan-kebijakan yang digunakan dalam mengatur roda pemerintahan yang dapat mencegah tindakan kecurangan yang terjadi dalam aktivitas pemerintahan. Informasi dan komunikasi yang dilakukan pada masa terdahulu tidak hanya untuk kepentingan publik tapi seraya memohon petunjuk kepada Yang Maha Esa dalam menetapkan berbagai hal. Informasi dan komunikasi ini dilaksanakan dalam bentuk diskusi-diskusi dengan mengundang para pejabat lainnya untuk memberikan laporan atas daerah yang dipimpinnya. Hal tersebut merupakan langkah preventif yang dilakukan untuk dapat mengawasi roda pemerintahan pada saat itu.

Setelah semua dilakukan sebagai bentuk pencegahan, maka langkah selanjutnya adalah melakukan pemantauan, pemantauan dilakukan secara langsung maupun tidak langsung. Beberapa pimpinan Islam terdahulu melakukan pemantauan secara langsung dengan mendatangi wilayah-wilayah para pejabat yang diberikan kepercayaan untuk memimpin daerah tersebut, sedangkan pemantauan secara tidak langsung yakni dengan meminta atau bertanya kepada pihak lain tentang gaya kepemimpinan dalam mengelola roda pemerintahan. Pemantauan tidak hanya dilakukan dari aspek perekomian saja namun sosial dan 
agama juga menjadi tujuan utamanya. Selain itu pemantauan dilakukan untuk menilai akuntabilitas pertanggungjawaban para pimpinan, mereka tidak hanya fokus pada pihak-pihak yang mengendalikan sumber daya namun mereka juga menilai bagaimana partisipasi masyarakat dalam memanfaatkan sumber daya.

Rokhlinasari dan Hidayat (2016) menyebutkan bahwa sistem pengendalian internal merupakan salah satu komponen esensial dalam lembaga keuangan syariah. Putriandini (2012) menyatakan seringkali nilai-nilai konvensional masih muncul pada pembiayaan yang diterapkan pada perbankan syariah.

Pola implementasi pengendalian internal pada pemerintahan jauh sebelum COSO dikenal sudah menggunakan basis syariah yakni dengan berpedoman pada Al-quran dan hadits, hal ini terlihat dari berbagai sifat dan gaya kepemimpinan yang tercermin dari tindakan pimpinan pada masa Islam yang dipaparkan pada penjelasan sebelumnya. Selain itu faktor spiritual (pemahaman keagamaan), sifat dan gaya kepemimpinan menjadi aspek yang penting dalam membentuk lingkungan pengendalian dan membangun roda pemerintahan yang sesuai dengan Al-quran dan hadits.

Komponen mendasar dalam pengendalian internal adalah berada pada lingkungan pengendalian. Lingkungan pengendalian memegang peranan yang sangat penting karena bertindak sebagai payung bagi komponen yang lain. Bila lingkungan pengendaliannya baik maka risiko yang akan dihadapi dapat diminimalisir dan seluruh aktivitas akan berjalan dengan baik, hal ini akan menciptakan kinerja yang kondusif dan dinamis dalam sebuah pemerintahan. Lingkungan pengendalian yang baik tercipta dari tingginya tingkat spiritualitas, sifat dan gaya kepemimpinan.

Prinsip utama lingkungan pengendalian adalah membentuk jiwa spiritual dan leadership, jika hal ini sudah ada dalam jiwa setiap pemimpin maka mereka akan patuh dalam melaksanakan perintahNYA dan menjauhi laranganNYA sehingga risiko-risiko atas kecurangan yang akan terjadi tidak akan terjadi karena bentuk komitmen yang dibangun tidak hanya didasarkan pada manusia namun dengan sang pencipta yakni Allah SWT. Rasa sungkan yang dimiliki akan mempengaruhi aktivitas pengendalian, sehingga mereka akan enggan untuk 
melakukan kekeliruan atau kesengajaan-kesengajaan yang akan mengganggu lingkungan kerja. Informasi dan komunikasi yang terjalin dengan baik akan memudahkan para pimpinan dalam menentukan kebijakan, untuk membuktikan informasi tersebut maka dilakukan monitoring, pemimpin negara tidak sungkan melakukan pengawasan secara langsung mereka bahkan meminta pihak lain menilai kinerja para pimpinan daerahnya masing-masing.

\section{SIMPULAN}

Selain lima komponen yang terdapat dalam pengendalian internal COSO beserta subkomponen yang mengikutinya, terdapat subkomponen lain yang dirasa perlu dimasukkan ke dalam salah satu subkomponen dalam lingkungan pengendalian, subkomponen tersebut adalah spiritualitas, sifat dan gaya kepemimpinan, artinya sebelum menjadi seorang pemimpin yang harus menciptakan lingkungan kondusif bagi kepemimpinannya. Prinsip utama dalam pengendalian internal berada pada lingkungan pengendalian. Lingkungan pengendalian memiliki peranan yang penting dalam pengendalian internal karena ia berperan sebagai payung bagi komponen pengendalian internal lainnya. Bila lingkungan pengendalian baik, maka resiko yang muncul dapat diminimalisir, aktivitas pengendalian akan berjalan dengan baik, informasi dan komunikasi dapat dijalin dengan baik dan pemantauan dapat dilakukan secara berkala.

Penelitian ini memberikan rekomendasi, yaitu: Pertama, bagi pemerintah agar mempelajari sifat dan keteladanan dari pemimpin-pemimpin muslim agar dapat mempertimbangkan sifat dan keteladanan untuk dapat dijadikan sebagai salah satu subkomponen dalam lingkungan pengendalian. Kedua, bagi peneliti selanjutnya agar dapat membahas lebih banyak lagi pemimpin muslim tidak hanya terbatas pada zaman Rasulullah sampai dengan Zaman kekhalifahan Turki Utsmani, namun membahas semua komponen dalam pengendalian internal berikut semua subkomponen yang terdapat didalamnya, dan melengkapi literature dengan sumber bacaan yang lebih banyak lagi. 


\section{PUSTAKA ACUAN}

Ali Ash-Shallabi, M. (2014). Umar bin Abdul Aziz. Jakarta: Pustaka Al-Kautsar.

Amalia, E. (2005). Sejarah Pemikiran Ekonomi Islam dari Masa Klasik hingga Kontemporer. Depok: Gramata Publishing.

Anugerah, R. (2014). Peranan Good Corporate Governance dalam Pencegahan Fraud. Jurnal Akuntansi Universitas Riau. Volume 3 (1): 71-80.

Darmawan, R. F., Atmadja, A. T., \& Darmawan, N. A. S. (2015). Analisis Sistem Pengendalian Intern dalam Pembiayaan Implan Pada PT Bank Syariah Mandiri (Studi Kasus Pada PT Bank Syariah Mandiri Kantor Cabang Pembantu Buleleng). E-Journal Universitas Pendidikan Ganesha. Vol. 3 (1): 110.

Jensen, M. C., \& Meckling, W. (1976). Theory of the Firm: Managerial Behavior, Agency Costs, and Ownership Structure. Journal of Financial Economic. Vol. 3: 305-360.

Morissan. (2015). Metode Penelitian Survei. Jakarta: Kencana.

Putriandini, S. (2012). Nilai-nilai Konvensional dalam Implementasi Sistem Pengendalian Internal Pada Pembiayaan Musyarakah: Sebuah Studi Fenomenologi. Jurnal Akuntansi Multiparadigma. Vol. 3(1): 1-21.

Rokhlinasari, S., \& Hidayat, A. (2016). Pengaruh Sistem Pengendalian Internal Terhadap Kualitas Laporan Keuangan Pada Bank BJB Syariah Cirebon. AlAmwal. Vol. 8(2): 491-508.

Sugiyono. (2013). Metode Penelitian Pendidikan Pendekatan Kuantitatif, Kualitatif, dan R\&D. Bandung: Alfabeta.

Tery, G. R. (1962). Office Management and Control. New Jersey: Nortwestern University.

Tunggal, A. W. (2016). Pengendalian Internal dan Pencegahan Kecurangan. Jakarta: Harvarindo. 